\title{
Charakter prawny postępowania w przedmiocie zastosowania środków zabezpieczających w polskim procesie karnym
}

\begin{abstract}
This paper focuses on the legal nature of proceedings to impose security (precautionary) measures. Given that their legal nature is determined by a set of different features characteristic of given proceedings, the study analyses modifications of proceedings to apply security measures which justify considering them a separate category. It is no doubt that the proceedings in question are criminal proceedings. However, the fact that they differ from the "model" criminal proceedings makes them an interesting subject of study. The findings indicate that the proceedings to impose security measures should be classified as special criminal procedings or more specifically, special proceedings of criminal process and thus it should be viewed as one of the so-called equivalent special proceedings.
\end{abstract}

Keywords: legal nature of proceedings, proceeding to impose security/precautionary measures, special criminal procedure, security measures, equivalent special procedure

$\mathrm{Na}$ wstępie niniejszych rozważań warto nadmienić, iż w doktrynie bardzo niewiele uwagi poświęca się problematyce charakteru prawnego postępowania w przedmiocie zastosowania środków zabezpieczających. Trudność budzi również odnalezienie definicji terminu „charakter prawny", gdyż wielu autorów zdaje się postrzegać go w sposób intuicyjny ${ }^{1}$.

${ }^{1}$ Tak np. M. CIEŚLAK: Polska procedura karna: podstawowe założenia teoretyczne. Warszawa 1984, s. 73-74 oraz 378-388; K. SychTA: Charakter prawny postęowania rehabilitacyjnego określonego ustawa z dnia 23.02.1991 r. RPEiS 2001, nr 4, s. 121-142; A. ŚwIATŁoWsKI: Jedna czy wiele procedur karnych: z zagadnień wewnętrznego zróżnicowania form postępowania karnego rozpoznawczego. Sopot 2008, s. 146-223; M. BŁAchUскI: Charakter prawny postępowania antymonopolowego. W: Nowe problemy badawcze $w$ teorii prawa administracyjnego. Red. J. Boć, A. Снајвоwicz. Wrocław 2009, s. 789-803; 
W niniejszym artykule przez owo pojęcie rozumiany będzie konglomerat cech, które wyznaczają tożsamość danego postępowania. W konsekwencji już na początku opracowania konieczne jest rozważenie przedmiotu postępowania w kwestii zastosowania środków zabezpieczających w celu udzielenia odpowiedzi na pytanie, czy jest ono postępowaniem karnym. Twierdzenie pozytywne skutkować będzie natomiast dalszymi dociekaniami w zakresie ulokowania omawianego postępowania $\mathrm{w}$ ramach jednego z rodzajów postępowania karnego. Nie ulega bowiem wątpliwości, iż zachodzące $\mathrm{w}$ postępowaniu w przedmiocie zastosowania środków zabezpieczających modyfikacje uzasadniają jego kategorialną odrębność.

Jak zauważono, charakter prawny analizowanego postępowania ściśle sprzężony jest $\mathrm{z}$ ustaleniem przedmiotu tegoż postępowania. $Z$ tego względu dla prowadzenia dalszych rozważań trzeba rozstrzygnąć kwestię wstępną, a mianowicie udzielić odpowiedzi na pytanie, jaki jest jego przedmiot. Wydawać by się mogło, że jest ona oczywista, jako że sama nazwa implikuje wniosek, iż przedmiot ten stanowi zastosowanie środków zabezpieczających. W rzeczywistości sprawa jest o wiele bardziej skomplikowana i warto przeanalizować ją w szerszej perspektywie, uwzględniając pojęcie przedmiotu samego procesu karnego. Zasygnalizowana kwestia zostanie więc bliżej omówiona w dalszej części tekstu.

Przedmiot procesu karnego określany jest $\mathrm{w}$ doktrynie $\mathrm{w}$ rozmaity sposób. Niezbędne wydaje się zatem dokonanie komparacji koncepcji poszczególnych autorów. Pierwotnie pojęcie to definiowano jako za przedmiot procesu uznawano czyn popełniony przez oskarżonego ${ }^{2}$. Takie spojrzenie na przedmiot postępowania determinowałoby postrzeganie za cel procesu karnego głównie ustalenia faktu popełnienia przestępstwa, a - jak powszechnie wiadomo - kluczowe znaczenie ma nadto wykrycie sprawcy i wyciągnięcie wobec niego konsekwencji prawnych ${ }^{3}$. Na gruncie polskim pierwszą refleksję dotyczącą przedmiotu procesu znaleźć można w podręczniku autorstwa S. Śliwińskiego z 1936 r., gdzie stwierdził on, że przedmiotem postępowania karnego jest zarzucony oskarżonemu $\operatorname{czyn}^{4}$, nie podając jednak argumentów na poparcie swojego stanowiska. Zaproponowaną tezę rozwinął natomiast w późniejszej publikacji, w której umieścił odrębny rozdział poświęcony problematyce przedmiotu procesu. S. Śliwiński utożsamił tam przedmiot postępowania karnego z roszczeniem, które przysługuje państwu wobec sprawcy przestępstwa. Teoria

K. MacıuK: Charakter prawny postępowania zabezpieczajacego. W: Tendencje prawa materialnego i procesowego cywilnego. Red. E. MarszaŁKowsKA-Krześ. Wrocław 2017, s. 127 i nast.

${ }^{2}$ S. Waltoś, P. Hofmański: Proces karny. Zarys systemu. Warszawa 2018, s. 25.

3 Ibidem.

4 S. ŚLIWIŃsKI: Proces karny - część ogólna. Warszawa 1936, s. 109. 
ta, określana mianem ius puniendi, wynika z postrzegania procesu jako stosunku prawnego. Każdy proces ma zatem za zadanie orzeczenie o roszczeniach wynikających ze zdarzenia faktycznego, jakim jest czyn zabroniony określonego człowieka. Państwo dysponuje natomiast uprawnieniem do stosowania wobec danej jednostki kary czy środków wychowawczych lub zabezpieczających ${ }^{5}$. Nie sposób nie zauważyć pewnej niekonsekwencji terminologicznej w rozważaniach wspomnianego autora, który raz jako przedmiot procesu wskazuje roszczenie karne państwa, a innym razem podstawę faktyczną tego roszczenia, czyli czyn przestępny. Tym niemniej powyższa koncepcja zyskała wsparcie w powojennym orzecznictwie Sądu Najwyższego, gdzie wielokrotnie stwierdzano, iż przedmiotem procesu jest czyn przestępny, który faktycznie zaistniał, tudzież zdarzenie faktyczne objęte aktem oskarżenia 6 .

Współcześnie teoria ius puniendi poddawana jest krytyce. Wśród zarzutów wskazać można aspekty terminologiczne związane z posługiwaniem się spornym pojęciem „roszczenie”, a także łączenie przedmiotu procesu ze stosunkiem materialnoprawnym. W konsekwencji przedmiot procesu nie istniałby w sytuacjach, w których finalnie okazałoby się, że w ogóle nie doszło do czynu ${ }^{7}$. M. Cieślak trafnie zaznaczył, że transferując pojęcia cywilistyczne na grunt prawa karnego, zapomniano o dystynkcjach pomiędzy tymi gałęziami prawa. Kara nie stanowi bowiem celu samego w sobie, ale środek do jego osiągnięcia, a w konsekwencji w określonych sytuacjach państwo rezygnuje z nałożenia tejże sankcji ${ }^{8}$. Podobnie inni przedstawiciele doktryny wskazywali, że koncepcja ius puniendi nie jest kompatybilna ze współczesnym postrzeganiem roli państwa i prawa karnego9. Natomiast L. Schaff zasygnalizował jej logiczną sprzeczność, gdyż w myśl jej założeń stosunek materialnoprawny (podstawa procesu) jest konsekwencją popełnienia czynu przestępnego, a zarazem ten właśnie czyn ma stanowić przedmiot ustaleń w postępowaniu ${ }^{10}$. Nietrafne wydaje się także zrównanie pozycji państwa i sprawcy przestępstwa poprzez przyjęcie, że ten ostatni dobrowolnie godzi się na wysunięcie przeciwko niemu

5 S. ŚLIwińsKI: Polski proces karny przed sądem powszechnym. Zasady ogólne. Warszawa 1961, s. 119 i nast.

${ }^{6}$ Wyr. SN z dnia 22 października 1953 r., II K 535/53. OSNCK 1954, nr 2, poz. 33, LEX nr 117592, a także wyr. SN z dnia 8 października 1955 r., IV KRn 555/55. OSNCK 1956, nr 3, poz. 48.

7 K. Marszat: Proces karny. Zagadnienia ogólne. Katowice 2013, s. 14-15.

${ }^{8}$ M. CieślaK: Proces karny. Zagadnienia ogólne. Kraków 1952, s. 46.

9 Tak np. L. LisiakieWicz: Ius puniendi czy metafizyka?. PiP 1963, nr 8-9, s. 220 i nast.

${ }^{10}$ L. SchafF: Wszczęcie postępowania karnego a problematyka podstawy i przedmiotu procesu. PiP 1959, nr 2, s. 246 i nast.; IDEM: Zakres i formy postępowania przygotowawczego. Warszawa 1961, s. 45 i nast. 
roszczenia. Założenie takie jest pewnego rodzaju fikcją, gdyż proces karny w znacznej mierze opiera się jednak na przymusie ${ }^{11}$.

Innowacyjne, kwestyjne ujęcie przedmiotu procesu pojawiło się w latach 50. XX w. za sprawą J. Marca, L. Schaffa, M. Cieślaka, a także W. Daszkiewicza. Koncepcja pierwszego z wymienionych autorów stanowiła zalążek poddania przedmiotu procesu innej optyce. Zasygnalizował on, że przedmiotem procesu jest merytoryczne orzeczenie o żądaniu wynikającym ze zdarzenia faktycznego, a proces ma doprowadzić do osądzenia zarzucanego sprawcy czynu ${ }^{12}$. Zaprezentowanej myśli J. Marzec nie rozwijał już jednak w swoich późniejszych publikacjach. Zdaniem L. Schaffa za przedmiot procesu uznać należy kwestię, wokół której skoncentrowany jest spór stron. W jego przekonaniu nie sposób z góry zdefiniować powyższe pojęcie, gdyż stanowi ono niejako rezultat toczącego się postępowania. Cały proces karny nacelowany jest bowiem na jego ustalenie i rozstrzygnięcie. Toteż w przekonaniu L. Schaffa przedmiotem postępowania karnego jest okoliczność, czy przestępstwo obiektywnie miało miejsce, czy też nie ${ }^{13}$. W pełni rozwinięta i kompletna wydaje się dopiero teoria M. Cieślaka, który traktuje przedmiot procesu jako kwestię odpowiedzialności prawnej danej jednostki za określony czyn przestępny. W tak pojmowanym przedmiocie zawarte są pytania o sam fakt popełnienia przestępstwa, osobę sprawcy i konsekwencje, które ma ona ponieść ${ }^{14}$. Podkreślić należy, iż fakt popełnienia przestępstwa nie stanowi wg M. Cieślaka przedmiotu procesu, ponieważ badanie rzeczywistości jest jedynie celem pośrednim, który umożliwić ma określenie odpowiedzialności i jej rozmiarów. Odpowiedzialność prawna dotyczy zatem nie czynu rzeczywistego, a procesowej hipotezy (podejrzenia, zarzutu), na której weryfikację nastawiony jest proces ${ }^{15}$. Sam autor zaznaczył, że choć jego podejście jest nowatorskie, to nadal uwaga skoncentrowana pozostaje na czynie przestępnym, ponieważ dla rozstrzygnięcia kwestii odpowiedzialności prawnej niezbędne jest uprzednie podjęcie decyzji co do czynu objętego zarzutem procesowym ${ }^{16}$. Podobny pogląd wyraził W. Daszkiewicz, który podkreślił nadto, iż owa odpowiedzialność prawna jest odpowiedzialnością sprawczą, i to ukształtowaną, a tym samym obejmuje wymierzenie negatywnych konsekwencji oraz ich wykonanie, a określony

\footnotetext{
11 S. Waltó́, P. Hofmański: Proces karny..., s. 26.

12 J. MARZEC: Z problematyki tożsamości czynu zarzucanego i przypisanego oraz wyboru właściwej klasyfikacji czynu. NP 1957, nr 12, s. 51.

13 L. SChafF: Wszczęcie postępowania karnego..., s. 246-260.

14 M. CIEŚlak: O pojęciu przedmiotu procesu $i w$ sprawie tzw. „podstawy procesu”. PiP 1959, nr 8-9, s. 333-341.

${ }^{15}$ K. Marszat: Proces karny. Zagadnienia..., s. 15-16.

${ }^{16}$ M. CIEŚLAK: O pojęciu przedmiotu..., s. 339-340.
} 
podmiot ponosi ją za własne czyny ${ }^{17}$. K. Dudka postrzega przedmiot procesu jako kwestię odpowiedzialności karnej oskarżonego za zarzucony mu czyn, co jest związane z faktem, iż od wejścia w życie nowelizacji wrześniowej (z dnia 27 września 2013 r.), tj. od dnia 1 lipca 2015 r., odpowiedzialność cywilna nie mieści się $\mathrm{w}$ ramach postępowania karnego na skutek rezygnacji z postępowania adhezyjnego. Owa odpowiedzialność karna obejmuje ustalenie faktu popełnienia przestępstwa, przypisanie oskarżonemu winy oraz wyciągnięcie konsekwencji prawnych ${ }^{18}$. S. Waltoś oraz P. Hofmański uznają za wskazane, aby rozważania na temat przedmiotu procesu rozpocząć od udzielenia odpowiedzi na dwa zasadniczo różne pytania. Po pierwsze ustalić należy, z jakiego powodu postępowanie się toczy. Nie ulega wątpliwości, że przyczyna tkwi w powzięciu uwiarygodnionej wiadomości o popełnionym przestępstwie. Cały proces stanowi zespół działań zmierzających do weryfikacji tej informacji. Następna kwestia dotyczy natomiast celu procesu. W toku postępowania dokonuje się subsumcji danego stanu faktycznego pod przepis ustawy, aby pociągnąc sprawcę do odpowiedzialności karnej, którą ten będzie zmuszony ponieść. W rezultacie przedmiot procesu jawi się jako problem odpowiedzialności karnej oskarżonego za zarzucone mu przestępstwo. Odpowiedzialność nie jest utożsamiana jednak z faktycznym jej poniesieniem, ale $\mathrm{z}$ decyzją o samej powinności jej poniesienia, do czego w rzeczywistości wcale nie musi dojść, np. w razie śmierci sprawcy ${ }^{19}$.

Reasumując, współcześnie w polskiej literaturze karnoprocesowej zasadnicze znaczenie ma teoria odpowiedzialności karnej oskarżonego za zarzucony mu czyn jako przedmiotu postępowania. Toteż taki sposób postrzegania przedmiotu postępowania karnego poddany zostanie dalszym rozważaniom. Na marginesie wskazać można jednak, iż nadal niektórzy autorzy posługują się terminem przedmiotu procesu $\mathrm{w}$ odniesieniu do objętego zarzutem czynu przestępnego, przy czym często zastrzegają oni, że zabieg taki stanowi jedynie symplifikację ${ }^{20}$.

Przełożenie przedstawionych stanowisk na płaszczyznę postępowania w przedmiocie zastosowania środków zabezpieczających rodzi niemałe trudności. Po pierwsze, wątpliwości budzi już zasadność pojęcia „odpowiedzialność prawna (karna)", gdyż środki zabezpieczające stosowane być mogą także wobec osób niepoczytalnych w chwili czynu, którym nie sposób przypisać jakąkolwiek odpowiedzialność. Sprzeczność ta zostaje

\footnotetext{
17 W. DaszKiewicz: Proces karny. Część ogólna. T. I. Toruń 1985.

18 K. Dudka. W: K. Dudka, H. Paluszkiewicz: Postępowanie karne. Warszawa 2017, s. 36.

19 S. Waltoś, P. Hofmański: Proces karny..., s. 26-27.

${ }^{20}$ Tak np. S. Kalinowski: Polski proces karny. Warszawa 1971, s. 11, a także T. GrzegORCZYK, J. Tylman: Polskie postępowanie karne. Warszawa 2007, s. 51.
} 
jednakże wyeliminowana poprzez szerokie rozumienie terminu „odpowiedzialność prawna”. W przekonaniu M. Cieślaka nazwa ta obejmuje wszelkie niekorzystne następstwa materialnoprawne, które zostaną orzeczone $\mathrm{w}$ razie udowodnienia oskarżonemu popełnienia czynu zabronionego, a wśród nich środki zabezpieczające ${ }^{21}$. Kolejny problem pojawia się na tle terminu „czyn przestępny” w definicji przedmiotu procesu karnego w ujęciu M. Cieślaka. Jak się wydaje, w odniesieniu do postępowania w przedmiocie zastosowania środków zabezpieczających winno się posługiwać pojęciem „czyn zabroniony”, jako że sprawcy niepoczytalnemu nie sposób przypisać winę, która stanowi obligatoryjny element struktury przestępstwa. Pamiętać bowiem należy, iż termin „przestępstwo” ma węższy zakres od terminu „,czyn zabroniony”. Elementy strukturalne przestępstwa można określić na podstawie art. 1 k.k. Zgodnie z tym przepisem przestępstwo to czyn człowieka zabroniony pod groźbą kary przez ustawę obowiązującą w czasie jego popełnienia, bezprawny, społecznie szkodliwy w stopniu wyższym niż znikomy oraz zawiniony. Nie trudno więc zauważyć, że każde przestępstwo będzie zarazem czynem zabronionym, jednakże nie każdy czyn zabroniony utożsamiać można z przestępstwem. Podsumowując, sam fakt realizacji ustawowych znamion umożliwia przyjęcie popełnienia czynu zabronionego przez sprawcę, u którego, ze względu na istniejące zaburzenia psychiczne, powstaje niemożność przypisania winy, a tym samym wykluczone jest popełnienie czynu przestępnego. Nadto zasadne jest zwrócenie uwagi na jeszcze jeden aspekt, a mianowicie na relację przedmiotu postępowania przygotowawczego toczącego się $\mathrm{w}$ danej sprawie do przedmiotu postępowania po złożeniu przez prokuratora wniosku, o którym mowa w art. 324 k.p.k. Środki zabezpieczające mogą być bowiem stosowane nie tylko w razie skazania, ale także wówczas, gdy postępowanie umorzono z uwagi na niepoczytalność sprawcy w chwili czynu. Zgodnie z art. $324 \$ 1$ k.p.k. jeżeli zostanie ustalone, że podejrzany dopuścił się czynu w stanie niepoczytalności, a istnieją podstawy do zastosowania środków zabezpieczających, prokurator po zamknięciu śledztwa kieruje sprawę do sądu z wnioskiem o umorzenie postępowania i zastosowanie środków zabezpieczających.

Warto w tym miejscu nadmienić, iż nie ma zgodności w kwestii, czy postępowanie prowadzone przez sąd na podstawie art. 354 k.p.k. stanowi działanie sądu w postępowaniu przygotowawczym, ograniczające się jedynie do przeprowadzenia określonych w ustawie czynności czy też skierowanie przez prokuratora wniosku w trybie art. 324 k.p.k. powoduje wszczęcie postępowania sądowego. Zwolennicy pierwszej koncepcji podnoszą, iż skierowanie do sądu wniosku o umorzenie postępowania

${ }^{21}$ M. CIEŚLAK: Polska procedura karna..., s. 298. 
i zastosowanie środków zabezpieczających prowadzi do zawisłości sprawy przed sądem, ale sąd w zakresie umorzenia postępowania działa jako organ uprawniony do określonych czynności w postępowaniu przygotowawczym, które ulegnie zakończeniu dopiero wskutek ewentualnego wydania orzeczenia w przedmiocie jego umorzenia ${ }^{22}$. Stanowisko to podziela m.in. J. Grajewskii ${ }^{23}$ czy E. Samborski ${ }^{24}$. Z całą stanowczością należy opowiedzieć się jednak za drugim poglądem. Wniosek o umorzenie postępowania i zastosowanie środków zabezpieczających pełni niewątpliwie funkcję inicjującą, a zatem jego złożenie przenosi postępowanie do fazy jurysdykcyjnej. Jak trafnie stwierdza Sąd Najwyższy, dochodzi do zakończenia postępowania przygotowawczego, a jednocześnie rozpoczęcia stadium postępowania sądowego, bez względu na to, że jego przedmiot ogranicza się do rozstrzygnięcia kwestii umorzenia postępowania i orzeczenia środka zabezpieczającego ${ }^{25}$. Na poparcie powyższego stanowiska wskazać można w ślad za Sądem Najwyższym następujące argumenty ${ }^{26}$. Po pierwsze, rozpoznanie wniosku z art. 324 k.p.k. następuje z reguły na rozprawie, która nie jest przewidziana w stadium postępowania przygotowawczego. Po drugie, do rozpoznania wniosku odpowiednio stosuje się przepisy dotyczące przygotowania do rozprawy głównej. Po trzecie, sąd rozpoznający wniosek prokuratora nie orzeka w składzie przewidzianym dla czynności sądowych w postępowaniu przygotowawczym. Po czwarte, przyjęcie odmiennego poglądu generowałoby konieczność stwierdzenia zbędności art. 354 pkt 1 k.p.k., jako że bezsporne jest, iż przepisy o oskarżycielu posiłkowym mogą mieć zastosowanie dopiero $\mathrm{w}$ sądowym stadium postępowania.

K. Zgryzek trafnie zauważa, iż zagadnienia prawne będące przedmiotem owego umorzonego postępowania są jednocześnie materialnoprawnymi przesłankami stosowania środków zabezpieczających (sprawstwo określonej osoby, jej stan psychiczny, stopień zagrożenia). Z tego względu uznać należy, iż dochodzi do sui generis kontynuacji postępowania przygotowawczego, gdyż sąd swoje rozstrzygnięcie w przedmiocie zastosowania określonego środka zabezpieczającego opiera głównie na ustaleniach

22 W. KociubińsKi: Orzekanie o środku zabezpieczajacym z art. 94 \$1 nowego kodeksu karnego w świetle nowego kodeksu postępowania karnego. PS 1999, nr 3, s. 129.

23 J. Grajewski: Przebieg procesu karnego. Warszawa 2001, s. 75-77 i 92-94.

${ }^{24}$ E. SAMBORSKI: Zarys metodyki pracy sędziego w sprawach karnych. Warszawa 2002, s. 102.

${ }^{25}$ Uchw. SN z dnia 26 września 2002 r., I KZP 13/02. OSNKW 2002, nr 11-12, poz. 88, LEX nr 54944 czy też post. SN z dnia 5 kwietnia 2001 r., IV KKN 652/00. LEX nr 51426, a także uchw. SN z dnia 25 lutego 2005 r., I KZP 35/04. OSNKW 2005, nr 2, poz. 14. LEX nr 143195.

${ }^{26}$ Uchw. SN z dnia 25 lutego 2005 r., I KZP 35/04. OSNKW 2005, nr 2, poz. 14, LEX nr 143195. 
poczynionych w trakcie owego postępowania. W konsekwencji nie ulega zmianie przedmiot procesu. Postępowanie przygotowawcze skupiało się wokół odpowiedzialności karnej danej jednostki za popełnione przestępstwo, zaś przedmiotem postępowania jurysdykcyjnego, toczącego się po złożeniu przez prokuratora rzeczonego wniosku, będzie inna kwestia szczegółowa w postaci zastosowania środków zabezpieczających ${ }^{27}$. Taki wniosek jest uzasadniony także w świetle poglądów M. Cieślaka, który zauważa, że określony rodzaj konsekwencji prawnych czynu może być analizowany, chociażby kwestia czynu została ostatecznie rozstrzygnięta ${ }^{28}$.

W obliczu poczynionych uwag uprawniona wydaje się konstatacja, iż przedmiot postępowania co do zastosowania środków zabezpieczających stanowi „kwestia odpowiedzialności prawnej danej osoby konkretyzująca się zastosowaniem wobec niej określonego rodzaju środka zabezpieczającego" 29 .

Po dokonaniu analizy zagadnień związanych z przedmiotem postępowania w kwestii zastosowania środków zabezpieczających warto zastanowić się nad jego nazwą. W literaturze nie poświęca się zbyt wiele uwagi wspomnianej materii. Także ustawodawca nie wprowadza żadnej nomenklatury dla określenia omawianego postępowania. Jak już wcześniej zauważono, literalne rozumienie nazwy „postępowanie w przedmiocie zastosowania środków zabezpieczających" może prowadzić do mylnych wniosków dotyczących rzeczywistego przedmiotu omawianego postępowania. A vista wydawać by się mogło bowiem, iż przedmiot ten stanowi jedynie samo zastosowanie środków zabezpieczających, a nie, jak wywiedziono wyżej, kwestia odpowiedzialności prawnej danej jednostki, która znajduje odzwierciedlenie w zastosowaniu wobec niej określonego środka zabezpieczającego.

M. Cieślak posługuje się pojęciem ,sądowego postępowania w kwestii środka zabezpieczającego"30. Analogicznie J. Grajewski wspomina o „postępowaniu w kwestii orzeczenia środka zabezpieczającego" ${ }^{31}$. Również Z. Doda pisze o ,postępowaniu w kwestii [...] stosowania środka zabezpieczającego $^{32}$. Zaznaczyć należy, że tylko M. Lipczyńska wprost określa omawiane postępowanie jako „,postępowanie w przedmiocie stosowania

${ }^{27}$ K. ZgryzeK: Postępowanie $w$ przedmiocie zastosowania środków zabezpieczajacych $w$ polskim procesie karnym. Katowice 1989, s. 52.

28 M. CIEŚlaK: Polska procedura karna..., s. 298.

${ }^{29}$ K. Zgryzek: Postępowanie $w$ przedmiocie..., s. 52.

30 M. Cieślak. W: M. Cieślak, K. Spett, W. Wolter: Psychiatria $w$ procesie karnym. Warszawa 1977, s. 133.

31 J. GrajewsKi: Ściganie na wniosek w polskim procesie karnym. Gdańsk 1982, s. 115.

32 Z. DodA: Zażalenie w procesie karnym. Warszawa 1985, s. 231. 
środków zabezpieczających"33, nawiązując do treści ówcześnie obowiązującego art. 223 k.p.k. z 1969 r. Zgodnie z tym przepisem, jeżeli z powodu niepoczytalności podejrzanego następuje umorzenie postępowania, można, niezależnie od terminów określonych w art. 222 k.p.k., orzec o utrzymaniu tymczasowego aresztowania do czasu zakończenia postępowania $\mathrm{w}$ sprawie lub $\mathrm{w}$ przedmiocie środka zabezpieczającego. Ustawodawca expressis verbis posłużył się zatem określeniem „w przedmiocie środka zabezpieczającego", które M. Lipczyńska wzbogaciła rzeczownikiem odczasownikowym „stosowania”, tworząc tym samym nazwę „postępowanie w przedmiocie stosowania środków zabezpieczających”. K. Zgryzek przychylnie ustosunkował się do zaproponowanej przez M. Lipczyńską terminologii, wskazując jednak, iż wymaga ona przekształcenia poprzez zastąpienie trybu niedokonanego czasownika „stosować” trybem dokonanym „zastosować”, co ma na celu właściwsze odzwierciedlenie charakteru orzeczenia kończącego omawiane postępowanie ${ }^{34}$.

Konkludując, za zasadne uznać należy posługiwanie się pojęciem „postępowanie w przedmiocie zastosowania środków zabezpieczających”. Nomenklatura ta znajduje zarówno potwierdzenie we wcześniejszych wywodach dotyczących przedmiotu analizowanego postępowania, jak i pośrednio w treści przepisu art. 324 k.p.k., w którym zawarto stwierdzenie, że prokurator po zamknięciu śledztwa kieruje sprawę do sądu z wnioskiem o umorzenie postępowania i zastosowanie środków zabezpieczających. Nie ulega bowiem wątpliwości, iż orzekanie o zastosowaniu środka zabezpieczającego jest tożsame $\mathrm{z}$ jego stosowaniem ${ }^{35}$, a zatem proponowana nazwa najpełniej będzie oddawała istotę omawianego postępowania oraz kończącego je rozstrzygnięcia. Postulować należy nadto jednolitość stosowania w doktrynie przyjętego nazewnictwa ${ }^{36}$.

Dokonanie powyższych ustaleń pozwala przejść do dalszych rozważań mających na celu określenie charakteru prawnego omawianego postępowania. Zbieżność przedmiotu postępowania w kwestii zastosowania środka zabezpieczającego z przedmiotem postępowania karnego prowadzi do stwierdzenia, iż to pierwsze jest postępowaniem karnym. Tezę tę wspiera nadto umieszczenie przepisów regulujących omawiany tryb w Kodeksie postępowania karnego ${ }^{37}$.

${ }_{33}$ M. LIPCZYŃsKa: Stosowanie środków zabezpieczających jako tryb szczególny procesu karnego. NP 1978, nr 1, s. 21.

34 K. ZgryzeK: Postępowanie $w$ przedmiocie..., s. 53-54.

35 Ibidem, s. 53.

36 Zamienne posłużenie się w niniejszym artykule słowem „kwestia” zamiast „przedmiot" w nazwie omawianego postępowania podyktowane jest wyłącznie względami stylistycznymi i nie stanowi odejścia od przyjętej nomenklatury.

37 K. Zgryzek: Postępowanie $w$ przedmiocie..., s. 54. 
Warto zastanowić się nad problemem, jakim rodzajem postępowania karnego jest omawiane postępowanie. Zdaniem W. Daszkiewicza ma ono charakter uzupełniający w stosunku do postępowania przygotowawczego ${ }^{38}$. Takie ujęcie omawianej kwestii spotkało się z krytyką K. Zgryzka, który odwołując się do słownikowej definicji słowa „uzupełnienie", wykazał nieadekwatność sformułowania, którym posługuje się W. Daszkiewicz. Używanie bowiem proponowanego przez niego terminu prowadziłoby do wniosku, iż postępowanie przygotowawcze nie stanowi zamkniętej całości i wymaga dopełnienia dodatkowym elementem w postaci postępowania $\mathrm{w}$ przedmiocie zastosowania środka zabezpieczającego. W rzeczywistości natomiast oba postępowania są odrębnymi od siebie całościami $^{39}$.

Niewątpliwie innowacyjną koncepcję przedstawiła M. Lipczyńska, proponując postrzeganie postępowania w przedmiocie zastosowania środków zabezpieczających jako szczególnego trybu postępowania karnego. Autorka ta wskazała na podobieństwo regulacji do postępowania prywatnoskargowego, które, chociaż było uregulowane częściowo w Kodeksie karnym, a częściowo w Kodeksie postępowania karnego, zostało zaklasyfikowane przez ustawodawcę do postępowań szczególnych ${ }^{40}$. Dodatkowo M. Lipczyńska zauważyła, że chociaż urzeczywistnienie jej postulatu stanowiłoby novum w polskiej tradycji legislacyjnej, to nie należy przypisywać w tej kwestii kluczowego znaczenia wykładni historycznej ${ }^{41}$.

Uznanie postępowania w przedmiocie zastosowania środków zabezpieczających za tryb szczególny zaproponowali także inni przedstawiciele doktryny $^{42}$. Konieczne wydaje się zatem poczynienie w tym miejscu kilku uwag odnoszących się do postępowań szczególnych w celu udzielenia odpowiedzi na pytanie, czy zasadne jest umieszczenie w tej kategorii postępowania w przedmiocie zastosowania środków zabezpieczających.

$\mathrm{Na}$ wstępie warto dokonać ustaleń terminologicznych. Zgodnie z przedstawioną przez S. Waltosia definicją przez pojęcie „,postępowanie szczególne” rozumieć należy taki przebieg postępowania karnego mającego na celu rozstrzygnięcie o odpowiedzialności karnej oskarżonego,

38 W. DAsZKIEWICZ: Glosa do postanowienia SN z dnia 3 listopada 1975 r. - Z 34/75. „Informacja Prawnicza” 1975, nr 11-12, s. 25.

${ }^{39}$ K. ZgryzeK: Postępowanie $w$ przedmiocie..., s. 54-55.

40 Postępowanie prywatnoskargowe zostało uregulowane w Rozdziale 44 ,postępowanie w sprawach z oskarżenia prywatnego" Działu X „postępowania szczególne” Ustawy z dnia 19 kwietnia 1969 roku - Kodeks postępowania karnego, Dz.U. 1969, nr 13, poz. 96 ze zm.

${ }^{41}$ M. LIPCZYŃsKa: Stosowanie środków zabezpieczajacych..., s. 21.

42 Tak np. J. NelKen: W sprawie zmian w unormowaniu stosowania leczniczych środków zabezpieczajacych. NP 1985, nr 4, s.77 czy też K. Zgryzek: Postępowanie w przedmiocie..., s. $55-56$. 
który różni się w sposób istotny, z góry przewidziany przez ustawodawcę od typowego przebiegu procesu uznanego za modelowy w danym systemie karnoprocesowym ${ }^{43}$. Jak stwierdza K. Marszał, „postępowanie szczególne" nie jest nazwą jednoznaczną. Pojęcie to utożsamiać należy z takim przebiegiem postępowania karnego, który, co prawda, zmierza do rozstrzygnięcia odpowiedzialności karnej oskarżonego, ale różni się od przebiegu procesu modelowego w danym systemie, gdyż uległ modyfikacjom $^{44}$. Definicja autorstwa K. Marszała wykazuje odmienność w komparacji do powołanej wyżej definicji S. Waltosia w postaci rezygnacji z wymogu istotności różnic w odniesieniu do postępowania typowego. Zabieg ten nie wydaje się słuszny, gdyż, jak celnie zauważa A. Światłowski, „aby mówić o postępowaniu szczególnym, liczba i waga odmienności muszą być na tyle znaczne, by dla postronnego, obiektywnego obserwatora wyodrębnione przez te odmienności postępowanie było wystarczająco inne od modelowego" 45 . W konsekwencji nie należy deprecjonować znaczenia wymogu wyrazistości różnic. Ponadto definicja K. Marszała ma charakter sprawozdawczy, a za kluczowe kryterium klasyfikacji danego postępowania w kategorii postępowań szczególnych autor ten zdaje się uznawać przyjęcie takiego określenia przez ustawodawcę ${ }^{46}$. Natomiast według W. Daszkiewicza postępowanie szczególne to postępowanie z mocy specjalnych przepisów cechujące się odmiennościami w stosunku do postępowania podstawowego ${ }^{47}$. Ujęcie to także uznać należy za mało precyzyjne, co w rezultacie prowadzić może do niezasadnego poszerzenia zbioru desygnatów terminu „postępowanie szczególne”.

Przytoczone definicje, pomimo pewnych odrębności, łączy wspólny rdzeń, a mianowicie dostrzeżenie tożsamości przedmiotu postępowań szczególnych i postępowania zasadniczego. Celowe wydaje się przyjęcie na potrzeby niniejszego artykułu rozumienia terminu ,postępowanie szczególne” w ślad za S. Waltosiem, jako że proponowana przez niego definicja wydaje się najpełniej oddawać istotę postępowań szczególnych, a nadto dość powszechnie aprobowana jest przez doktrynę ${ }^{48}$.

$\mathrm{Na}$ marginesie wspomnieć wypada, iż w literaturze przedmiotu trafnie stosuje się zamiennie pojęcia „postępowanie” i „tryb”, co czyni także

43 S. Waltoś: Postępowania szczególne $w$ procesie karnym (postępowania kodeksowe). Warszawa 1973, s. 11.

${ }^{44}$ K. Marszat: Przebieg procesu karnego. Cz. 4: Postępowania szczególne. Katowice 1979, s. 5.

45 A. ŚwiAtŁowsKi: Jedna czy wiele procedur karnych..., s. 58-59.

${ }^{46}$ Ibidem, s. 47 i 56.

47 W. Daszkiewicz: Proces karny..., s. 59-60.

48 Wielu autorów przywołuje ją wprost bądź z niewielkimi zmianami, a wśród nich np. J. Grajewski: Przebieg procesu karnego..., s. 357 czy też T. GrzegorczyK, J. Tylman: Polskie postępowanie karne..., s. 861. 
ustawodawca ${ }^{49}$. Korzystając z narzędzi wykładni gramatycznej, stwierdzić można, iż pojęcia te są równoznaczne, ponieważ postępowanie oznacza tryb działania sądu, natomiast wśród synonimów słowa „tryb” wskazać można procedurę, metodę czy też sposób postępowania ${ }^{50}$. Nie należy jednak tracić z pola widzenia faktu, iż nazwa „tryb” bywa również stosowana w innym znaczeniu. Odnosić można ją bowiem także do sposobu ścigania, na co uwagę zwraca m.in. S. Waltośs ${ }^{51}$.

Próbę merytorycznego zróżnicowania wskazanych pojęć podjął A. Światłowski. W jego przekonaniu termin „postępowanie szczególne” łączyć należy z łańcuchem powiązanych ze sobą czynności i innych zdarzeń zmierzających do urzeczywistnienia pewnego celu. Natomiast pojęcie „tryb szczególny” oznacza pewien sposób działania. Zdaniem tego autora tryb szczególny stanowi sposób zróżnicowania postępowania karnego, natomiast postępowanie szczególne jest wynikiem owej dywersyfikacji. Ostatecznie przychyla się jednak do zamiennego używania obydwu pojęć ${ }^{52}$, co uznać należy za w pełni słuszne.

Na kanwie poczynionych uwag zauważyć należy, iż skoro postępowania szczególne stanowią odstępstwo od trybu zasadniczego, powinny spełniać pewne wymogi. Niewątpliwie konieczne jest, aby powody tworzenia postępowań szczególnych cechowała istotność pozwalająca uzasadnić celowość wprowadzania odstępstw od zwykłego przebiegu procesu. Ponadto sposób uregulowania przebiegu postępowania szczególnego umożliwiać winien prawidłowe rozstrzygnięcie kwestii odpowiedzialności prawnej oskarżonego za dany czyn zabroniony. Wreszcie wprowadzone modyfikacje nie mogą naruszać gwarancyjnej funkcji prawa karnego procesowego ${ }^{53}$.

Konstatując, wydaje się, iż postępowanie w przedmiocie zastosowania środków zabezpieczających z powodzeniem można zaliczyć do kręgu postępowań szczególnych. Nie ulega bowiem wątpliwości, iż skierowane jest ono na rozstrzygnięcie o przedmiocie procesu karnego, a jego przebieg wyraźnie różni się od postępowania modelowego, co zostanie syntetycznie wykazane w dalszej części artykułu. Ponadto, jak słusznie zauważa K. Zgryzek, ,potraktowanie omawianego postępowania jako postępowania szczególnego może [...] przynieść efekt nie tylko w postaci uporząd-

49 D. Kala: Tryby szczególne $w$ kodeksie postępowania karnego $w$ świetle poglądów prezentowanych $w$ doktrynie i judykaturze. Toruń 2005, s. 15.

50 Tak np. L. DrabiK, E. Sobol: Stownik języka polskiego. Warszawa 2004, s. 584 i 803 czy też E. Soвol: Stownik języka polskiego. Warszawa 2005, s. 394 i 732, a także W. CienKowsкi: Praktyczny stownik wyrazów bliskoznacznych. Warszawa 1993, s. 189 i 268.

51 S. Waltoś, P. Hofmański: Proces karny..., s. 42-43.

52 A. ŚwiatŁowsKi: Jedna czy wiele procedur karnych..., s. 60-62.

${ }_{53}$ M. TużNIK: Postępowania szczególne $w$ postępowaniu karnym skarbowym. Warszawa 2013, s. 36-37. 
kowania i kompleksowego uregulowania wszystkich pojawiających się na tym tle zagadnień. Ale nadto pozwoli to na jasne wytyczenie granic regulacji szczególnej. I wreszcie sprzyjać będzie dochowaniu gwarancyjnego charakteru norm postępowanie to regulujących" ${ }^{54}$.

Na marginesie wskazać wypada, iż, jak powszechnie wiadomo, możliwość procedowania w trybie szczególnym uzależniona jest od kumulatywnego wystąpienia zarówno ogólnych, jak i szczególnych przesłanek postępowania. Te ostatnie najczęściej mają charakter przesłanek dodatkowych, które występują obok warunków ogólnych ${ }^{55}$. Tym niemniej pamiętać należy o przypadkach, kiedy dany tryb szczególny warunkują tylko niektóre przesłanki ogólne oraz dodatkowe przesłanki szczególne ${ }^{56}$. Nie można także wykluczyć sytuacji, w której określona przesłanka ogólna staje się przesłanką szczególną. Tak się dzieje w przypadku przesłanki niepoczytalności, która to dla trybu zwykłego stanowi ogólną przeszkodę procesową, a dla postępowania w przedmiocie zastosowania środków zabezpieczających może występować jako przesłanka szczególna pozytywna ${ }^{57}$. W kontekście przesłanek procesowych nie można tracić także z pola widzenia przepisu art. 17 § 3 k.p.k., w myśl którego niemożność przypisania winy sprawcy czynu nie wyłącza postępowania dotyczącego zastosowania środków zabezpieczających. Z regulacji tej expressis verbis wynika, iż brak możliwości przypisania danej osobie winy nie stanowi przeszkody procesowej dla wszczęcia postępowania w przedmiocie zastosowania środków zabezpieczających. Określona w powołanym przepisie sytuacja stanowi zatem wyjątek od ogólnej zasady, iż wystąpienie negatywnej przesłanki procesowej generuje konieczność odmowy wszczęcia bądź umorzenia postępowania ${ }^{58}$. Znacznie przekracza jednakże ramy niniejszego artykułu szczegółowa analiza poszczególnych przesłanek warunkujących dopuszczalność postępowania w przedmiocie zastosowania środków zabezpieczających, toteż celowe wydaje się ograniczenie wywodu jedynie do ich wyliczenia. Do kategorii przesłanek ogólnych postępowania w przedmiocie zastosowania środków zabezpieczających zaliczyć należy: podsądność sądom karnym, właściwość sądu, skargę, istnienie stron procesowych, prawomocność materialną, zawisłość sprawy, przedawnienie oraz abolicję. Zdaniem K. Zgryzka w powyższej grupie przesłanek znajduje się także wniosek o ściganie, gdyż „spełnia identyczne funkcje, co prze-

${ }^{54}$ K. ZgryzeK: Postępowanie $w$ przedmiocie..., s. 55-56.

55 J. SкоRUPKa. W: Proces karny. Red. IDEM. Warszawa 2017, s. 232.

56 M. CIEŚLAK: O przesłankach procesowych w polskim postępowaniu karnym. Podstawowe założenia i problemy metodologiczne. Prok. i Pr. 1969, nr 12, s. 959.

57 K. Zgryzek: Postępowanie $w$ przedmiocie..., s. 61.

${ }_{58}$ M. Kurowski. W: Kodeks postępowania karnego. Komentarz. T. I. Red. D. Świecki. Warszawa 2018, s. 156. 
słanka tej kategorii w stosunku do trybu zwykłego" 59 . Natomiast do przesłanek szczególnych omawianego postępowania zaklasyfikować trzeba: wniosek prokuratora o zastosowanie środka zabezpieczającego, zakończenie postępowania przygotowawczego, prawomocność formalną postanowienia o zamknięciu śledztwa (z oczywistych względów przesłanka ta nie będzie miała zastosowania, jeżeli postępowanie przygotowawcze toczyło się $\mathrm{w}$ formie dochodzenia) oraz szereg przesłanek zakotwiczonych $\mathrm{w}$ prawie materialnym.

Zakwalifikowanie postępowania $\mathrm{w}$ przedmiocie zastosowania środków zabezpieczających do kategorii trybów szczególnych postępowania karnego powoduje dalsze implikacje teoretycznoprawne. Nieodzowne jest rozważenie, do której grupy trybów szczególnych należy przedmiotowe postępowanie. Przyjmując za kryterium formalizm danego trybu szczególnego w stosunku do postępowania typowego, wyróżnić można trzy grupy trybów szczególnych. Pierwsza obejmuje postępowania wzbogacone o elementy dodatkowe w porównaniu do trybu zwykłego. Jako przykład trybu wzbogaconego wskazać można tryb postępowania przed sądami przysięgłych, który obowiązywał do 1938 r. i miał zastosowanie w sprawach o najcięższe przestępstwa. Postępowania drugiej grupy charakteryzuje zredukowany przebieg, a tym samym skierowane są głównie do spraw o przestępstwa mniejszej wagi. Zaś trzecia obejmuje postępowania równoważne, których formalizm procesowy nie został ani wzbogacony, ani zmniejszony. Prawidłowe zrozumienie istoty postępowań ekwiwalentnych wymaga kilku uwag. Fakt, iż formalizm tej grupy trybów szczególnych nie uległ rozszerzeniu ani zawężeniu nie oznacza, że nie wprowadzono żadnych modyfikacji. W przeciwnym razie bezpodstawne byłoby uznawanie takowego postępowania za szczególne. Postępowania tej grupy cechuje zawsze zastąpienie pewnych elementów występujących w trybie zwykłym innymi elementami. Liczba modyfikacji może być różna, przy czym nie może dojść do takiego zachwiania proporcji w stosunku do trybu zwykłego, które skutkowałoby istotnym zwiększeniem bądź zmniejszeniem formalizmu.

K. Zgryzek opowiedział się za sklasyfikowaniem postępowania w przedmiocie zastosowania środków zabezpieczających wśród postępowań drugiej grupy ${ }^{60}$. Konstatacja taka niewątpliwie straciła na aktualności w związku ze zmianą stanu prawnego w wyniku wejścia w życie Kodeksu postępowania karnego z dnia 6 czerwca 1997 r. ${ }^{61}$, a w konsekwencji należy zastanowić się, do którego rodzaju trybów szczególnych zaliczyć

${ }^{59}$ K. ZgryzeK: Postępowanie $w$ przedmiocie..., s. 62.

${ }^{60}$ Ibidem, s. 56.

${ }^{61}$ Ustawa z dnia 6 czerwca 1997 r. - Kodeks postępowania karnego, Dz.U. 2018, poz. 1987 ze zm. 
omawiane postępowanie na gruncie obowiązujących przepisów. Dla udzielenia odpowiedzi na postawione pytanie niezbędne jest poruszenie kilku zagadnień. Omówienie poniżej wskazanych kwestii pozwoli bowiem ocenić stopień sformalizowania postępowania $\mathrm{w}$ przedmiocie zastosowania środków zabezpieczających, co jest niezbędne, by ostatecznie wywieść wniosek o jego zredukowaniu, równoważności bądź też wzbogaceniu.

Niewątpliwie należy zwrócić uwagę na wymagania formalne wniosku, sporządzanego lub zatwierdzanego przez prokuratora, o umorzenie postępowania i zastosowanie środków zabezpieczających, składanego na podstawie art. 324 \$ 1 k.p.k. Zarówno w doktrynie, jak i w orzecznictwie liczne kontrowersje budzi kwestia, czy wniosek o umorzenie postępowania i zastosowanie środków zabezpieczających stanowi substytut aktu oskarżenia czy też należy sklasyfikować go w kategorii innych skarg zasadniczych. Zwolennicy uznania wniosku z art. 324 k.p.k. za inną skargę zasadniczą ${ }^{62}$ jako koronny argument na poparcie swojego stanowiska przedstawiają okoliczność, iż w razie nieuwzględnienia przedmiotowego wniosku przez sąd sprawa zostaje przekazana prokuratorowi, a zatem sąd nie kontynuuje procedowania w celu wydania merytorycznego rozstrzygnięcia ${ }^{63}$. Nie wydaje się, aby teza ta zasługiwała na aprobatę. Pamiętać należy wszak, że również w wyniku wstępnej kontroli aktu oskarżenia przewidzianej w Rozdziale 40 k.p.k. w myśl przepisu art. 337 § 1 k.p.k. może dojść do zwrotu aktu oskarżenia oskarżycielowi, a tym samym ustania stanu zawisłości sprawy przed sądem. Odmiennie wniosek o umorzenie postępowania składany w trybie art. 324 k.p.k. klasyfikują m.in. S. Waltoś czy też H. Paluszkiewicz, postrzegając go w kategorii skargi substytuującej akt oskarżenia ${ }^{64}$. Również w orzecznictwie pojawiają się zarówno głosy, iż wniosek o umorzenie postępowania i zastosowanie środków zabezpieczających, jako że spełnia wymogi formalne aktu oskarżenia, stanowi jego surogat $^{65}$, jak i stanowiska przeciwne ${ }^{66}$.

${ }^{62}$ Tak np. W. Sych: Wniosek prokuratora o umorzenie postępowania $i$ zastosowanie środków zabezpieczających jako szczególny rodzaj skargi w polskim procesie karnym. W: Skargowy model procesu karnego. Księga ofiarowana Profesorowi Stanisławowi Stachowiakowi. Red. A. Gerecka-ŻoŁyńsKa et al. Warszawa 2008, s. 362 czy też M. BŁoński, B. Najman: Umorzenie postępowania wskutek cofnięcia aktu oskarżenia. „Studia Prawno-Ekonomiczne” 2015, nr 94, s. 33.

${ }^{63}$ Tak np. S. Stachowiak. W: K. Marszae, S. Stachowiak, K. ZgryzeK: Proces karny. Katowice 2003, s. 425.

${ }^{64}$ S. Waltoś, P. Hofmański: Proces karny..., s. 278 oraz H. Paluszkiewicz. W: K. Dudka, H. Paluszkiewicz: Postępowanie karne..., s. 469.

${ }_{65}$ Post. SA w Katowicach z dnia 23 sierpnia 2017 r., II AKz 534/17. LEX nr 2401046.

${ }^{66}$ Zanegowanie możliwości uznania wniosku z art. 324 k.p.k. za surogat aktu oskarżenia - m.in. wyr. SO w Poznaniu z dnia 23 czerwca 2015 r., IV Ka 555/15. Źródło: http:// 
Zauważyć należy, że poza sporem jest, iż mianem skarg zastępujących akt oskarżenia winno się określać skargi zasadnicze o analogicznych funkcjach, jak akt oskarżenia, ale nim niebędące ${ }^{67}$. Z powyższego względu rozważyć trzeba, czy wniosek o umorzenie postępowania i zastosowanie środków zabezpieczających spełnia wskazane kryterium. Wniosek ten niewątpliwie odgrywa rolę programową, zakreślając granice podmiotowe i przedmiotowe rozpoznania sprawy, poza które sąd nie może wykraczać. Stanowi on także podsumowanie postępowania przygotowawczego i przenosi poczynione $\mathrm{w}$ nim ustalenia do etapu jurysdykcyjnego, a tym samym pełni funkcję bilansującą. Realizuje również zadania informacyjne, gdyż zawarte są w nim wszelkie pozyskane wiadomości dotyczące popełnionego przez sprawcę czynu. Porównując funkcje spełniane przez wniosek składany w trybie art. 324 k.p.k. oraz akt oskarżenia, należy zatem dojść do konkluzji, iż jest on składany w miejsce tego ostatniego. W konsekwencji trzeba stwierdzić, iż stanowi substytut skargi zasadniczej. Pogląd taki znajduje także wsparcie normatywne w przepisach regulujących wymogi formalne wniosku. W myśl art. 324 §1a k.p.k. do rzeczonego wniosku stosuje się odpowiednio przepisy dotyczące aktu oskarżenia (art. $331 \S 1$ i $§ 4$, art. 332, art. 333 §1-3 i art. 334 § 1 k.p.k.). Wykluczyć zatem należy twierdzenie, jakoby formalizm ulegał tutaj zredukowaniu. Zasadnicza różnica pomiędzy wskazanymi pismami procesowymi sprowadza się jedynie do tego, że wniosek składany na podstawie art. $324 \$ 1$ k.p.k. wskazuje na konieczność umorzenia postępowania i zastosowania środków zabezpieczających, zaś akt oskarżenia inicjuje postępowanie nacelowane na skazanie sprawcy.

Niejako na marginesie poczynionych uwag zasadne wydaje się spojrzenie na wniosek z art. 324 k.p.k. także z punktu widzenia zasady legalizmu. W postępowaniu karnym przez legalizm rozumie się obowiązek ścigania przestępstw ściganych $\mathrm{z}$ urzędu ${ }^{68}$. Tym samym organy państwa nie mają w tym zakresie swobody i nie mogą podejmować decyzji opartej na kryterium celowości. Normatywny wyraz zasady legalizmu stanowi art. 10 k.p.k., zgodnie z którym organ powołany do ścigania przestępstw jest obowiązany do wszczęcia i przeprowadzenia postępowania przygotowawczego, a oskarżyciel publiczny także do wniesienia i popierania oskarżenia - o czyn ścigany z urzędu. Z wyjątkiem wypadków określonych $\mathrm{w}$ ustawie lub w prawie międzynarodowym nikt nie może być zwolniony od odpowiedzialności za popełnione przestępstwo. Organy państwa zobligowane są zatem do podjęcia stosownych działań w razie samego tylko

orzeczenia.poznan.so.gov.pl/content/\$N/153510000002006_IV_Ka_000555_2015_ Uz_2015-07-02_001 [dostęp: 16.03.2019].

${ }^{67}$ H. Paluszkiewicz. W: K. Dudka, H. Paluszkiewicz: Postępowanie karne..., s. 466.

${ }^{68}$ K. Marszat: Proces karny. Zagadnienia..., s. 91. 
uprawdopodobnienia faktu popełnienia przestępstwa. Przeciwieństwem zasady legalizmu jest zasada oportunizmu, która polega na uprawnieniu do ścigania przestępstw i umożliwieniu jego zaniechania ze względu na stwierdzenie braku celowości wszczęcia i prowadzenia postępowania $^{69}$. Wyróżnić można oportunizm właściwy, który odwołuje się do interesu społecznego, oraz oportunizm niewłaściwy, który ma miejsce w sytuacji, gdy powodem odstąpienia od ścigania jest jedynie mała waga przestępstwa $^{70}$.

Z przepisu art. 324 § 1 k.p.k. wynika, że jeżeli zostanie ustalone, iż podejrzany dopuścił się czynu w stanie niepoczytalności, a istnieją podstawy do zastosowania środków zabezpieczających, prokurator po zamknięciu śledztwa ma obowiązek skierowania sprawy do sądu z wnioskiem o umorzenie postępowania i zastosowanie środków zabezpieczających. Tym samym zauważyć można, że polski ustawodawca w odniesieniu do wniosku z art. 324 k.p.k. zdecydowanie preferuje legalizm. Rozwiązanie to uznać trzeba za jak najbardziej słuszne. Prokurator, jako dominus litis, uprawniony jest dokonać oceny ziszczenia się przesłanek uzasadniających zastosowanie środków zabezpieczających, a w momencie ich ustalenia ma obowiązek skierować do sądu wniosek, o którym mowa w art. 324 k.p.k. Od tej chwili ciężar dalszych decyzji zostaje przerzucony na sąd, który jest jedynym organem właściwym do wydania orzeczenia w sprawie potrzeby zastosowania środków zabezpieczających. Powracając, w rezultacie poczynionej dygresji, do rozważań dotyczących formalizmu postępowania $\mathrm{w}$ przedmiocie zastosowania środków zabezpieczających, uprawniony wydaje się wniosek, że także pełne obowiązywanie zasady legalizmu, którego wyraz stanowi normatywne zobligowanie prokuratora do złożenia w określonych okolicznościach wniosku z art. 324 k.p.k., świadczy o równoważności przedmiotowego trybu $\mathrm{w}$ stosunku do postępowania zwyczajnego.

Kolejną kwestią jest forum rozpoznania wniosku z art. 324 k.p.k. Zgodnie z treścią art. 354 pkt 2 k.p.k. jest on co do zasady kierowany na rozprawę, a jedynie wyjątkowo na posiedzenie, jeśli w świetle materiałów postępowania przygotowawczego popełnienie czynu zabronionego przez podejrzanego i jego niepoczytalność w chwili czynu nie budzą wątpliwości, a prezes sądu uzna to za celowe. W konsekwencji skierowanie wniosku do rozpoznania na posiedzeniu obwarowane jest wymogiem kumulatywnego spełnienia dwóch przytoczonych przesłanek. Pierwszą z nich utożsamiać należy wyłącznie z sytuacją, kiedy zebrany w sprawie materiał dowodowy w sposób jednoznaczny i niebudzący jakichkolwiek wąt-

${ }^{69}$ Ibidem.

70 M. CIEŚLAK, Z. Doda: Kierunki orzecznictwa Sądu Najwyższego w zakresie postępowania karnego (lata 1980-1983). Pal. 1984, nr 10, s. 292. 
pliwości przesądza o sprawstwie i niepoczytalności podejrzanego. Druga przesłanka ma charakter znacznie bardziej ocenny, co generuje ryzyko nadużywania możliwości kierowania sprawy na posiedzenie, przyjmując za kryterium wzgląd na szybkość postępowania. Byłoby to niewątpliwie zjawisko niepożądane. Podkreślenia wymaga bowiem, że możliwość rozpoznania sprawy na posiedzeniu stanowi wyjątek od reguły kierowania wniosku na rozprawę, a tym samym regulacja ta nie podlega wykładni rozszerzającej. Jedynie rozprawa w pełni gwarantuje ochronę praw podejrzanego poprzez przeprowadzenie postępowania dowodowego bezpośrednio przed składem orzekającym. Takie ukształtowanie forum orzekania również wskazuje na równoważność ze zwykłym trybem.

$\mathrm{Na}$ uwagę zasługuje także problematyka uczestników analizowanego postępowania. Artykuł 339 § 5 k.p.k. stanowi, że strony, obrońcy i pełnomocnicy mogą wziąć udział w posiedzeniu w kwestii zastosowania środka zabezpieczającego, z tym że udział prokuratora i obrońcy w posiedzeniu w przedmiocie orzeczenia środka zabezpieczającego określonego $\mathrm{w}$ art. 93a § 1 pkt 4 k.k. (umieszczenie w zakładzie psychiatrycznym) jest obowiązkowy. Jak się wydaje, lex specialis w stosunku do powyższego przepisu stanowi art. 354 pkt 2 k.p.k., zgodnie z którym udział podejrzanego w posiedzeniu jest obowiązkowy, chyba że z opinii biegłych wynika, iż byłby on niewskazany. Podejrzany mimo to uczestniczy jednak w posiedzeniu, jeśli sąd uzna to za konieczne. Stąd rozpoznanie sprawy na posiedzeniu bez udziału podejrzanego nastąpić może jedynie wyjątkowo. $\mathrm{Z}$ powyższego wynika, że organ procesowy zobowiązany jest do zapewnienia podejrzanemu rzeczywistej partycypacji w posiedzeniu. Tym samym, jeżeli podejrzany byłby tymczasowo aresztowany, za nieuniknione uznać trzeba zarządzenie doprowadzenia go na posiedzenie, gdyż niewystarczające jest poprzestanie na zawiadomieniu go o jego terminie ${ }^{71}$. Co więcej, uprawniona zdaje się konkluzja, iż rozpoznanie sprawy pod nieobecność podejrzanego, jeżeli konieczność taka nie wynika z opinii biegłych, stanowi uchybienie określone w art. 439 § 1 pkt 11 k.p.k., a zatem bezwzględną przyczynę odwoławczą.

Inaczej sytuacja przedstawia się, gdy wniosek rozpoznawany jest na rozprawie. Wtedy udział prokuratora i obrońcy jest obligatoryjny, natomiast pokrzywdzony i jego pełnomocnik mają prawo wziąć udział w rozprawie. Zgodnie z art. 374 §1 k.p.k. w zw. z art. 380 k.p.k. podejrzany ma prawo wziąć udział $\mathrm{w}$ rozprawie, a jego obecność obowiązkowa jest jedynie wtedy, gdy przewodniczący lub sąd tak postanowią. Należy jednak dążyć do tego, aby także w przypadku rozprawy udział podejrzanego był realizowany w możliwie jak najszerszym zakresie, gdyż sąd po-

\footnotetext{
${ }^{71}$ Post. SN z dnia 5 kwietnia 2001 r., IV KKN 652/00. LEX nr 51426.
} 
winien mieć możliwość bezpośredniego kontaktu z daną osobą, by móc w pełni ukształtować sobie jej obraz i zweryfikować treść opinii biegłych w świetle wrażeń wynikających z osobistego odbioru zachowania podejrzanego. Wielce niekorzystnym zjawiskiem byłoby nadużywanie możliwości rezygnacji z bezpośredniego kontaktu z podejrzanym, np. z uwagi na względy estetyczne. Takie postępowanie organów procesowych stanowiłoby bowiem z całą stanowczością wystąpienie wbrew istocie funkcji gwarancyjnej postępowania karnego. W konsekwencji rozpoznanie sprawy pod nieobecność podejrzanego następować winno jedynie wówczas, gdy jest to nieodzowne dla jego dobra z uwagi na stan psychiczny, w którym się znajduje.

Można by się zastanawiać, czy w odniesieniu do uczestników postępowania $\mathrm{w}$ przedmiocie zastosowania środków zabezpieczających w pewnym zakresie nie mamy do czynienia z zaostrzeniem formalizmu. Tytułem przykładu wskazać można, iż w świetle art. 46 §2 k.p.k. jeżeli postępowanie przygotowawcze zakończyło się w formie dochodzenia, niestawiennictwo oskarżyciela publicznego na rozprawie nie tamuje jej toku, co implikuje wniosek, że udział prokuratora w rozprawie głównej stanowi w powyższej sytuacji jego prawo, a nie obowiązek. Zaś wobec uchylenia art. 325c k.p.k. postępowanie przygotowawcze wobec sprawcy niepoczytalnego może toczyć się także w formie dochodzenia.

$\mathrm{Na}$ koniec warto powołać również art. 354a §1 k.p.k., który obliguje sąd do wysłuchania biegłego psychologa, a w sprawach określonych podmiotów ponadto innych wskazanych biegłych przed orzeczeniem środka zabezpieczającego, o którym mowa w art. 93a §1 k.k., albo nakazu lub zakazów, o których mowa w art. 39 pkt 2-3 k.k., orzeczonych tytułem środka zabezpieczającego. W myśl § 2 powyższa regulacja nie ma jednak zastosowania, jeżeli sprawca, wobec którego istnieją podstawy do orzeczenia terapii lub terapii uzależnień, wyraża zgodę na taką terapię. Sąd może jednak, jeżeli uzna to za wskazane, wysłuchać jednego lub więcej biegłych wskazanych w tym przepisie. Wprowadzenie obligatoryjnego dowodu z opinii biegłych świadczy o zwiększeniu formalizmu omawianego postępowania i pełni niewątpliwie funkcję gwarancyjną.

Należy rozważyć w tym miejscu także, w jakim składzie sąd orzeka $\mathrm{w}$ przedmiocie zastosowania środków zabezpieczających. Zastosowanie znajdą reguły ogólne, a tym samym formalizm nie ulega ani zawężeniu, ani rozszerzeniu. Wydaje się jednak, że de lege ferenda zgłosić trzeba w ślad za K. Zgryzkiem postulat, aby orzekanie o środkach zabezpieczających zostało przekazane do wyłącznej kompetencji sądów okręgowych i to w składzie trzech sędziów zawodowych ${ }^{72}$. Regulacja taka byłaby niewątpliwie

\footnotetext{
72 K. ZgryzeK: Postępowanie $w$ przedmiocie..., s. 73-74.
} 
wskazana z punktu widzenia ochrony praw człowieka. Nie można tracić z pola widzenia faktu, że zastosowanie środka zabezpieczającego wiąże się ze znaczną dolegliwością dla osoby, której dotyczy. Nadto środki zabezpieczające orzekane są na czas z góry nieoznaczony, co dodatkowo pogarsza sytuację jednostki, wobec której są stosowane. Niemałe trudności powoduje także samo ustalenie przesłanek zastosowania środków zabezpieczających oraz dokonanie oceny materiału dowodowego, a w szczególności dowodu z opinii biegłych czy też wyjaśnień sprawcy. Z powyższych względów zasadne jest, aby przedmiotowa decyzja podejmowana była przez skład kolegialny, którego członkowie posiadają spore doświadczenie zawodowe.

Uwagi wymaga także forma rozstrzygnięcia sądu. Stosownie do dyspozycji art. $93 \$ 1$ k.p.k. niezależnie od tego, czy sprawa rozpoznawana była na posiedzeniu czy na rozprawie, orzeczenie zapada $\mathrm{w}$ formie postanowienia. Na stanowisku takim stoi także Sąd Najwyższy, twierdząc, że ustawodawca nie rozstrzyga, co prawda, wprost kwestii postaci orzeczenia, jakie powinno zapaść na rozprawie, jednakże nie należy zapominać o ogólnej regule wynikającej z art. 93 \$ 1 k.p.k., zgodnie z którą sąd orzeka wyrokiem jedynie wówczas, gdy ustawa tego wymaga, a przy braku takiego wymogu rozstrzyga postanowieniem ${ }^{73}$. Taka regulacja sugerować może zredukowanie formalizmu w stosunku do zwykłego trybu. Trzeba jednak zaznaczyć, że jeżeli do sądu skierowany został akt oskarżenia, a niepoczytalność sprawcy ujawniła się $\mathrm{w}$ trakcie przewodu sądowego, to zgodnie z art. 414 § 1 k.p.k. sąd orzeknie wyrokiem.

Odnotować wypada, iż wobec sprawców poczytalnych i sprawców z ograniczoną poczytalnością ustawodawca nie przewiduje odrębnego trybu orzekania o zastosowaniu środków zabezpieczających, a tym samym stosuje się przepisy ogólne. Obowiązkowe jest jednak wysłuchanie biegłych, co, jak już zauważono, w pewnym zakresie wzbogaca przebieg postępowania.

Poczynione wyżej refleksje prowadzą do konstatacji, że formalizm omawianego trybu szczególnego będzie w większości kwestii zbieżny $\mathrm{z}$ formalizmem trybu zwykłego, a tym samym postępowanie w przedmiocie zastosowania środków zabezpieczających zakwalifikować należałoby do grupy postępowań szczególnych o równoważnym przebiegu.

$\mathrm{Na}$ koniec, w świetle wysnutego wniosku, warto zastanowić się nad sposobem wprowadzania modyfikacji regulacji postępowania $\mathrm{w}$ przedmiocie zastosowania środków zabezpieczających. Nadmienić należy, iż w polskim ustawodawstwie funkcjonowało kilka metod wyróżniania

${ }^{73}$ Uchw. SN z dnia 19 sierpnia 1999 r., I KZP 21/99. OSNKW 1999, nr 9-10, poz. 49, LEX nr 37092. 
trybów szczególnych. Zgodnie z pierwszą z nich, zastosowaną w k.p.k. z 1928 r., tryby szczególne wyodrębniono z pierwotnie utworzonego trybu zwyczajnego i miały one względem niego charakter równoległy. Oznacza to, iż tryby szczególne istniały obok trybu zwyczajnego, którego przepisy miały do nich zastosowanie wprost, gdy dana kwestia nie została uregulowana szczególnie. Inna metoda zastosowana została w k.p.k. z 1969 r., a następnie zaadaptowana do k.p.k. z 1997 r. Na skutek jej wprowadzenia w obrębie postępowań szczególnych doszło do ich stratyfikacji ze względu na sposób dokonywania modyfikacji w stosunku do trybu zwykłego. W efekcie wskazać można było postępowania pierwszego i drugiego stopnia. Do postępowania pierwszego stopnia w sprawach nieuregulowanych zastosowanie znajdowały unormowania trybu zasadniczego, którego było ono modyfikacją. Z kolei postępowanie drugiego stopnia stanowiło metamodyfikację, gdyż w pierwszym rzędzie odmienność odnosić należało do określonego postępowania pierwszego stopnia i przepisy tegoż trybu stosować w braku uregulowań odmiennych ${ }^{74}$. Za sprawą nowelizacji z dnia 27 września 2013 r. uchylony został w całości rozdział poświęcony postępowaniu uproszczonemu ${ }^{75}$. W konsekwencji doszło do przemodelowania w obrębie postępowań szczególnych, tzn. przyjęto strukturę jednopoziomową w miejsce metody „kolejnych wyjść" ${ }^{76}$. W związku z powyższym w obecnie obowiązującym Kodeksie postępowania karnego modyfikacje do postępowania w przedmiocie zastosowania środków zabezpieczających wprowadzane są jednostopniowo, gdyż w kwestiach nieuregulowanych zastosowanie znajdują wprost przepisy regulujące postępowanie zwyczajne.

Reasumując, celem niniejszego artykułu była refleksja nad charakterem prawnym postępowania w przedmiocie zastosowania środków zabezpieczających. Jak zaznaczono na wstępie, charakter prawny wyznaczany jest przez pewien konglomerat cech danego postępowania, które świadczą o jego tożsamości. Nie budzi kontrowersji teza, iż będące przedmiotem niniejszego artykułu postępowanie jest postępowaniem karnym. Jednakże szereg dystynkcji cechujących omawiane postępowanie skłania do dalszych rozważań nad jego naturą, gdyż zostało ono ukształtowane w sposób odbiegający od wzorca. Analiza wyróżnionych w toku powyższego wywodu odrębności postępowania w przedmiocie zastosowania środków zabezpieczających przekonuje o zasadności sklasyfikowania go

74 K. EichstaedT: Postępowania szczególne w polskim prawie karnym. Warszawa 2010, s. 17.

75 Ustawa z dnia 27 września 2013 r. o zmianie ustawy - Kodeks postępowania karnego oraz niektórych innych ustaw, Dz.U. 2013, poz. 1247 ze zm.

76 Podano za: S. Waltoś: Postępowania szczególne w procesie karnym..., s. 21-22. 
w kategorii trybów szczególnych procesu karnego. Komparacja formalizmu omawianego postępowania z formalizmem trybu zwyczajnego prowadzi natomiast do konkluzji, iż postępowanie w przedmiocie zastosowania środków zabezpieczających należy zaliczyć do grupy postępowań szczególnych o równoważnym przebiegu.

\section{Bibliografia}

\section{Literatura}

BŁACHUCKI M.: Charakter prawny postepowania antymonopolowego. W: Nowe problemy badawcze $w$ teorii prawa administracyjnego. Red. J. Boć, A. CHAJBowicz. Wrocław 2009.

BŁoŃsKi M., NaJMAn B.: Umorzenie postępowania wskutek cofnięcia aktu oskarżenia. „Studia Prawno-Ekonomiczne” 2015, nr 94.

CIENKOWSKI W.: Praktyczny słownik wyrazów bliskoznacznych. Warszawa 1993.

CIEśLAK M.: O pojęciu przedmiotu procesu i w sprawie tzw. „podstawy procesu”. PiP 1959, nr 8-9.

CIEŚLAK M.: O przestankach procesowych $w$ polskim postępowaniu karnym. Podstawowe założenia i problemy metodologiczne. Prok. i Pr. 1969, nr 12.

CIEśLAK M.: Polska procedura karna: podstawowe zatożenia teoretyczne. Warszawa 1984.

CIEŚLAK M.: Proces karny. Zagadnienia ogólne. Kraków 1952.

Cieślak M. W: M. CieślaK, K. Spett, W. Wolter: Psychiatria $w$ procesie karnym. Warszawa 1977.

CieślaK M., Doda Z.: Kierunki orzecznictwa Sądu Najwyższego w zakresie postępowania karnego (lata 1980-1983). Pal. 1984, nr 10.

Daszkiewicz W.: Glosa do postanowienia SN z dnia 3 listopada 1975 r. - Z 34/75. „Informacja Prawnicza” 1975, nr 11-12.

Daszkiewicz W.: Proces karny. Część ogólna. T. I. Toruń 1985.

Doda Z.: Zażalenie w procesie karnym. Warszawa 1985.

DrabiK L., Sobol E.: Stownik języka polskiego. Warszawa 2004.

Dudka K. W: K. Dudka, H. Paluszkiewicz: Postępowanie karne. Warszawa 2017.

Eichstaedt K.: Postępowania szczególne $w$ polskim prawie karnym. Warszawa 2010.

GrajeWsKi J.: Przebieg procesu karnego. Warszawa 2001.

GRAJEWSKI J: Ściganie na wniosek w polskim procesie karnym. Gdańsk 1982.

GrzegorczyK T., Tylman J.: Polskie postępowanie karne. Warszawa 2007.

Kala D.: Tryby szczególne $w$ kodeksie postępowania karnego $w$ świetle pogladów prezentowanych $w$ doktrynie i judykaturze. Torun 2005.

KaLINOWski S.: Polski proces karny. Warszawa 1971.

KocIubińsкi W.: Orzekanie o środku zabezpieczajacym z art. 94 \$ 1 nowego kodeksu karnego w świetle nowego kodeksu postępowania karnego. PS 1999, nr 3.

Kurowsкi M. W: Kodeks postępowania karnego. Komentarz. T. I. Red. D. ŚwIECKI. Warszawa 2018. 
LIPCZYŃSKA M.: Stosowanie środków zabezpieczających jako tryb szczególny procesu karnego. NP 1978, nr 1.

LISIAKIEWICZ L.: Ius puniendi czy metafizyka?. PiP 1963, nr 8-9.

MaciuK K.: Charakter prawny postępowania zabezpieczajacego. W: Tendencje prawa materialnego i procesowego cywilnego. Red. E. MarszaŁKowsKa-Krześ. Wrocław 2017.

Marszat K.: Proces karny. Zagadnienia ogólne. Katowice 2013.

Marsza€ K.: Przebieg procesu karnego. Cz. 4: Postępowania szczególne. Katowice 1979.

MARZEC J.: Z problematyki tożsamości czynu zarzucanego i przypisanego oraz wyboru właściwej klasyfikacji czynu. NP 1957, nr 12.

NeLKen J.: W sprawie zmian $w$ unormowaniu stosowania leczniczych środków zabezpieczajacych. NP 1985, nr 4.

Paluszkiewicz H. W: K. Dudka, H. Paluszkiewicz: Postępowanie karne. Warszawa 2017.

SAMBORSKI E.: Zarys metodyki pracy sędziego w sprawach karnych. Warszawa 2002.

Schaff L.: Wszczęcie postępowania karnego a problematyka podstawy i przedmiotu procesu. PiP 1959, nr 2.

SCHAFF L.: Zakres i formy postępowania przygotowawczego. Warszawa 1961.

SKOrupKa J. W: Proces karny. Red. IdEM. Warszawa 2017.

Sobol E.: Słownik języka polskiego. Warszawa 2005.

Stachowiak S. W: K. Marszae, S. Stachowiak, K. Zgryzek: Proces karny. Katowice 2003.

SYcH W.: Wniosek prokuratora o umorzenie postępowania i zastosowanie środków zabezpieczajacych jako szczególny rodzaj skargi w polskim procesie karnym. W: Skargowy model procesu karnego. Ksiega ofiarowana Profesorowi Stanisławowi Stachowiakowi. Red. A. GERECKA-ŻoŁYŃsKA et al. Warszawa 2008.

SYCHTA K.: Charakter prawny postępowania rehabilitacyjnego określonego ustawa $z$ dnia 23.02.1991 r. RPEiS 2001, nr 4.

ŚLIWIŃSKI S.: Polski proces karny przed sądem powszechnym. Zasady ogólne. Warszawa 1961.

ŚLIWIŃsKi S.: Proces karny - część ogólna. Warszawa 1936.

ŚWIATŁOWSKI A.: Jedna czy wiele procedur karnych: z zagadnień wewnętrznego zróżnicowania form postępowania karnego rozpoznawczego. Sopot 2008.

TuŻNIK M.: Postępowania szczególne w postępowaniu karnym skarbowym. Warszawa 2013.

Waltoś S.: Postępowania szczególne w procesie karnym (postępowania kodeksowe). Warszawa 1973.

Waltoś S., Hofmański P.: Proces karny. Zarys systemu. Warszawa 2018.

ZGRYZEK K.: Postępowanie $w$ przedmiocie zastosowania środków zabezpieczajacych w polskim procesie karnym. Katowice 1989.

\section{Orzecznictwo}

Uchw. SN z dnia 19 sierpnia 1999 r., I KZP 21/99. OSNKW 1999, nr 9-10, poz. 49, LEX nr 37092. 
Uchw. SN z dnia 26 września 2002 r., I KZP 13/02. OSNKW 2002, nr 11-12, poz. 88, LEX nr 54944.

Uchw. SN z 25 lutego 2005 r., I KZP 35/04. OSNKW 2005, nr 2, poz. 14, LEX nr 143195.

Wyr. SN z dnia 22 października 1953 r., II K 535/53. OSNCK 1954, nr 2, poz. 33, LEX nr 117592.

Wyr. SN z dnia 8 października 1955 r., IV KRn 555/55. OSNCK 1956, nr 3, poz. 48.

Post. SN z dnia 5 kwietnia 2001 r., IV KKN 652/00. LEX nr 51426.

Post. SA w Katowicach z dnia 23 sierpnia 2017 r., II AKz 534/17. LEX nr 2401046.

Wyr. SO w Poznaniu z dnia 23 czerwca 2015 r., IV Ka 555/15. 